\title{
Chemical Element Levels as a Methodological Tool in Forensic Science
}

\author{
Gianni Gallello ${ }^{* 1,3}$, Julia Kuligowski ${ }^{2}$, Agustin Pastor ${ }^{3}$, Agustin Diez $^{1}$ and Joan Bernabeu ${ }^{1}$ \\ ${ }^{1}$ Department of Prehistory and Archaeology, University of Valencia, Valencia, Spain \\ ${ }^{2}$ Division of Neonatology, University Hospital Materno-Infantil La Fe, Bulevar Sur, Valencia, Spain \\ ${ }^{3}$ Department of Analytical Chemistry, University of Valencia, Burjassot, Valencia, Spain \\ "Corresponding author: Gianni Gallello, Department of Prehistory and Archaeology, University of Valencia, 28 Blasco Ibáñez Street, 46010 Valencia, Spain, Tel: \\ +34697636957; Fax: +34 96 3544838; E-mail: gianga@postal.uv.es
}

Rec date: Nov 10, 2014 Acc date: Dec 15, 2014 Pub date: Dec 20, 2014

Copyright: () 2014 Gallello G. This is an open-access article distributed under the terms of the Creative Commons Attribution License, which permits unrestricted use, distribution, and reproduction in any medium, provided the original author and source are credited.

\begin{abstract}
The aim of the present study was to define a methodological strategy for understanding how post- mortem degradation in bones caused by the environment affects different skeletal parts and for selecting better preserved bone samples, employing rare earth elements (REEs) analysis and multivariate statistics. To test our methodological proposal the samples selected belong to adult and young individuals and were obtained from the Late Roman Necropolis of c/Virgen de la Misericordia located in Valencia city centre (Comunidad Valenciana, Spain).

Therefore, a method for the determination of major elements, trace elements and REEs in bone remains has been developed employing Inductively-Coupled Plasma - Optical Emission Spectroscopy (ICP-OES) and ICP-Mass Spectrometry (MS). Bone samples, mainly rib and femur, from seventy-four individuals have been studied. Principal Component Analysis (PCA) was employed to facilitate the interpretation of the taphonomic processes. A multivariate classification model employing Partial Least Squares Discriminant Analysis (PLSDA) was used to identify bones with less soil contamination.parameters show that diet profiles of a population could change depending on the type of bones analyzed. The proposed method could be useful in forensic science investigations to select better preserved samples in different scenarios.
\end{abstract}

Keywords: Forensic science; Rare Earth Elements (REEs); Trace elements; Major elements; Soil diagenesis; Multivariate statistics; Human bones

\section{Introduction}

Chemical elements reach the body by being ingested from food or from environmental exposure. Determinations of chemical element in bones are employed to investigate pathologies, nutrition, injuries and other forensic issues.

The structure and chemical composition of bones can be modified post-mortem by diagenesis processes and since many decades researchers have been intensively studying these natural mechanisms. Some authors have investigated post-mortem soil contamination in bones [1-6]. Other authors have studied diagenesis degradation effects in bone matrix [7-9]. Post-mortem toxic metal bone contaminations (e.g. arsenic and lead) have been also investigated by authors $[10,11]$.

More recently, Rare earth element (REEs) analysis have been performed for monitoring the impact of diagenetic processes in fossil bones [12-18]. Post-mortem trace element chemistry of bone minerals could be potentially a sensitive indicator of the early depositional and hence the burial locality. However, to be useful as a tracer for a burial locality, target elements must meet several criteria such as: i) vary significantly between environments; ii) not be present in living tissues; iii) be incorporated rapidly and easily into bones post-mortem. They must be not subject to significant fractionation after initial incorporation into the bone [19]. In many studies, REEs have been shown to potentially provide these characteristics. The total REEs concentrations in bones in vivo are typically of the order of $<<1 \mathrm{ppm}$
$[20,21]$. They do not have known physiological functions and elevated concentrations are not present in food. Due to their little biological uptake, there is no known difference of REEs concentrations between taxonomic or dietary groups. The rate of incorporation of REEs into bones varies with the depositional environment. Variation in REEs composition in bones between and across depositional environments has been shown in several works [18,22-29]. Different intra-skeletal studies can be found in literature. Some works have carried out bone density fractionation studies separating bones of different mineral densities taking into account post-mortem degradation processes [30-32]. Other authors have studied mineralogical and structural postmortem changes observing variations at intra and inter-skeletal scales [33]. Intra-skeletal comparative studies involving chemical analysis of femurs and ribs also have been carried out; ribs have been found to be more sensitive to diagenetic processes [34]. However, currently no data have been published about diagenetic processes impact in bones as humerus, skull, tibia, radius that could be also employed for biochemical studies.

The general aim of the present study was to define a methodological strategy to understand how post- mortem degradation in bones caused by the environment, affects different skeletal parts and define an approach to select bone samples, employing mayor, trace elements and REEs analysis with multivariate statistics.

Therefore, a method for the determination of chemical elements in bone remains has been developed employing Inductively-Coupled Plasma Optical Emission Spectroscopy (ICP-OES) and ICP-MassSpectrometry (MS). Two hundred eighty nine samples obtained from seventy-four individuals have been analyzed. The samples selected belong to adult and young individuals and derive from the Late 
Roman Necropolis of c/Virgen de la Misericordia discovered in 1992 [35], located in Valencia city centre (Comunidad Valenciana, Spain). The Late Roman burial rite consisted in inhumation. At this site, the tombs belong to the period that lasted from the I century A.D. until the beginning of the $\mathrm{V}$ century A.D.

Bone samples have been collected mainly from femur and rib. In addition, some bones from other skeletal areas have been sampled (tibia, humerus, radius and parietal). Furthermore, bone samples from the outer bone layer and soil samples have been analyzed. Outer bone layer samples were obtained from the internal and external bone surface directly in contact with the sediments. Principal Component Analysis (PCA) and a classification model employing Partial Least Squares Discriminant Analysis (PLSDA) were applied to identify bone samples with a better preserved elemental composition. Diet reconstruction has been carried out employing different bones classes. $\mathrm{Zn} / \mathrm{Ca}$ relations to identify higher or lower protein intake and $\mathrm{Sr} / \mathrm{Ca}$ to identify pastoral or agricultural diet studies have been employed to test interpretive errors.

\section{Materials and Methods}

\section{Samples}

The samples employed to test our methodological proposal come from the Late Roman necropolis of c/ Virgen de la Misericordia located in the city centre of Valencia (Spain). This necropolis was discovered during a salvage archaeological intervention between 1992 and 1993 [35]. At this site, the tombs belong to the period that lasted from the I century A.D. until the late III century A.D. or the beginning of the V century A.D. The analyzed bones, dated between the III and IV centuries A.D., are from seventy-four adult and young individuals. The Late Roman burial rite consisted in inhumation and has been documented in different typologies of thumbs. The most frequent type of grave consisted in a pit that could house the body directly or in a coffin of wood or a ceramic container. Pits with a cover of tegulae and in some cases pits with walls and bottom coated in mortar and covered with two-slope tegulae, tegulae cist graves, tombs with semi-decked tegulae, tombs with tumulus in opus cementicium and receptacle made of brick walls, plastered and covered with two-slope tegulae, and tombs made of opus cementicium with rectangular vaulted chamber covered tumulus were also found. In general the graves hosted one individual. In the oldest graves until the second half of the first century A.D. the offering consisted in pottery and some glass. At the end of this century and the beginning of the second century A.D. they were composed of a single piece of ceramic or sometimes a coin in the mouth of the individual and from the third century A.D. the habit of placing dowries inside the tombs seems to disappear.

When it was feasible, for each individual different skeletal areas have been sampled, including mainly femur and rib and in some cases bones from other parties (tibia, humerus, radius and cranium). Bone samples from the outer bone layer have been analysed in order to detect elemental differences between the bones and their external part induced by diagenetic factors. All bone samples have been buried under the same environmental conditions, therefore, soil samples obtained from the surface of the bones have been analysed to understand the chemical relation between bone surface and sediment.

\section{Chemical analysis of bone samples}

The bone samples have been mainly taken from cortical tissue of seventy-four individuals (except one spongy tissue sample). The sampling was carried out taking different classes of bones of each individual. The two hundred eighty nine samples (bones, bone surfaces and soils) have been sampled using a cutting toll and a micro spoon spatula made by stainless steel, respectively, always cleaned before taking a new sample and stored in test tubes. Outer bone layer samples were obtained from the internal and external bone surface directly in contact with the sediments employing a bistoury to scrape. Sample preparation and digestion have been carried out as described by Gallello et al., [36]. The process include a thermal treatment at $450^{\circ} \mathrm{C}$ and successively the samples were crushed, homogenized and pestle by an agate mortar. The digestion method and concentration ranges of the dilutions from the digested solution were optimized in order to provide reproducible and comparable results compatible with the sensitivity of the analytical methods employed.

The digestion method consisted in the addition of $1.5 \mathrm{ml} \mathrm{HCl}$ and $1.5 \mathrm{ml} \mathrm{HNO}_{3}$ to $0.5 \mathrm{~g}$ of sample (bones and soil) in glass tubes placing them in a water bath at $100^{\circ} \mathrm{C}$ for $40 \mathrm{~min}$. Subsequently, the digested solutions have been carefully poured into plastic tubes of $15 \mathrm{ml}$, bringing the volume to $15 \mathrm{ml}$ with purified water. This concentrated solution (A), was used to measure trace elements such as $\mathrm{Zn}, \mathrm{Cu}, \mathrm{Ba}$ and $\mathrm{Mn}$. For the analysis of $\mathrm{Bi}, \mathrm{V}, \mathrm{Pb}, \mathrm{Cd}, \mathrm{Cr}, \mathrm{Co}, \mathrm{Li}, \mathrm{Mo}, \mathrm{Ni}$, Tl, REEs (La, Ce, Pr, Nd, Sm, Eu, Gd, Tb, Dy, Ho, Er, Tm, Yb, Lu, Sc and Y, solution (A) was diluted 1:10 obtaining solution (B). To measure $\mathrm{Mg}$ and Sr, solution (A) was diluted 1:250 obtaining solution (C). Solution (D) was obtained to analyze Ca from diluting solution (A) 1:2000. Concentrations of $\mathrm{HCl}$ and $\mathrm{HNO} 3$ have been maintained constant in all solutions. A multi-elemental stock solution containing $\mathrm{Ca}, \mathrm{Mg}, \mathrm{Sr}$, $\mathrm{Ba}, \mathrm{Cu}, \mathrm{Zn}, \mathrm{Pb}, \mathrm{Mn}, \mathrm{Cd}, \mathrm{Bi}, \mathrm{V}, \mathrm{Pb}, \mathrm{Cd}, \mathrm{Cr}, \mathrm{Co}, \mathrm{Li}, \mathrm{Mo}, \mathrm{Ni}$, Tl, REEs, Sc and $\mathrm{Y}$ at a concentration of $100 \mu \mathrm{g} / \mathrm{ml}$ was prepared. For the preparation of the calibration standards, $50 \mathrm{ml}$ volumetric flasks were used adding $5 \mathrm{ml}$ of $\mathrm{HNO}_{3}, 5 \mathrm{ml}$ of $\mathrm{HCl}$ and the corresponding volume of standard solution and filling up to volume with pure water. Solution (A), (C) and (D) were analyzed by ICP-OES with a Perkin Elmer 5300 DV (Norwalk, CT, USA) and solution (B) was analyzed by ICP-MS with Perkin Elmer Elan DRCII (Concord, Ontario, Canada). To avoid the obstruction of the nebulizer system samples were filtered employing filter paper (Whatman ${ }^{\mathrm{TM}} \mathrm{N} .1$ of $70 \mathrm{~mm}$ ). Concentrations ranging between 0 and $20 \mu \mathrm{g} / \mathrm{ml}$ have been used for major and trace elements $(\mathrm{Ca}, \mathrm{Mg}, \mathrm{Sr}, \mathrm{Ba}, \mathrm{Cu}, \mathrm{Zn}, \mathrm{Mn})$. Concentrations ranging between 0 and $0.6 \mu \mathrm{g} / \mathrm{ml}$ have been used for trace elements $(\mathrm{Bi}, \mathrm{V}, \mathrm{Pb}$, $\mathrm{Cd}, \mathrm{Cr}, \mathrm{Co}, \mathrm{Li}, \mathrm{Mo}, \mathrm{Ni}, \mathrm{Tl}, \mathrm{La}, \mathrm{Ce}, \mathrm{Pr}, \mathrm{Nd})$, and concentrations ranging between 0 and $0.1 \mu \mathrm{g} / \mathrm{ml}$ for Sm, Eu, Gd, Tb, Dy, Ho, Er, Tm, Yb, Lu. All standards were acquired from Sharlab S.L. (Barcelona). The standard error of readings during the analysis ranged from $0 \%$ to $2 \%$ for mayor elements, from $1 \%$ to $3 \%$ for trace elements and from $3 \%$ to 9\% for REEs. Bone ash NIST 1400 and soil GBW07408 have been used as standard reference materials for evaluating the analytical method. Re was used as internal standard for ICP-OES and Rh for ICP-MS analyses.

\section{Data analysis}

For statistical analysis thirty-two bone samples from femur, sixtyfour from rib, twenty- two bones of other type (four from parietal, eight from tibia, five humerus, one radius, one large bone, one child's humerus, one child's large bone, one child's spongy bone), thirty-two outer layer of femur, sixty-two outer layer of rib, and fifty five soils 
Page 3 of 9

(seven samples of soil close to the femur, twenty-one samples of soil close the rib, fourteen soil of the necropolis, thirteen soil close to the other type of bones) have been employed. All variables (i.e. elements) have been used for modeling.

PCA was used to explore large geochemical datasets thus, reducing the number of variables and providing a deeper insight into the structure of the variance of the dataset [37]. For PCA all rib, femur, the corresponding samples from the outer bone layers and the soil samples have been employed resulting in a data set with two hundred fourtyfour samples and thirty-three variables. Autoscaling was used as a preprocessing step prior to modeling. Partial least squares discriminant analysis (PLSDA) is a frequently used classification method [38-41]. Here, it has been applied to differentiate between digenetic states of bone samples. For model calibration, two out of three bone samples classified as rib (fourty-two samples) and femur (twenty-two) were selected, resulting in a calibration set with sixty-four samples and thirty-three variables. The remaining rib (twenty-two) and femur (ten) bone samples were used as an external validation set with the dimensions thirty-two samples by thirty-three variables for evaluating model performance. Four parietals (skull), eight tibiae, five humeri, one radius, one large bone, one child's humerus, one child's large bone and one child's spongy bone were included in the test set to predict their class, resulting in a matrix composed by twenty-two samples and thirty-three variables. Autoscaling and cross validation employing random sub-sets with four data splits and seven iterations were used. The optimum number of latent variables for calculating the PLSDA model was established by means of the misclassification rate of the calibration dataset. To assess the statistical significance of selected predictive quality parameters of the established PLSDA model, permutation testing was carried out employing the calibration set and 1000 permutations. Permutation testing is based on the comparison of the predictive capabilities of a PLSDA model using real class assignments to a number of models calculated after random permutation of the class labels. Briefly, a permutation test is a simulation of the null hypothesis of no difference between classes [42]. Scrambled models should provide worse figures of merit than the original model, if that model could not have arisen by chance.

Data analysis have been carried out using the PLS Toolbox 6.5 (Eigenvector Research Inc., Wenatchee, WA, USA) running in Matlab R2012b (Mathworks Inc., Natick, MA, USA).

\section{Results and Discussion}

\section{Determination of the elemental composition of bone samples employing ICP-OES and ICP-MS}

Once sample preparation had been developed as described in the methodology, analyses have been performed by ICP-OES and ICP-MS. Thirty-three elements were analysed including mayor elements, trace elements and REEs. The analytical emission wavelengths, mass, instrumental detection and quantification limit (LOD and LOQ, respectively) and $\mathrm{R}^{2}$ is listed in Table 1 for ICP-OES and ICP-MS analysis. To allow comparisons between standards and samples, measurement units are $\mu \mathrm{g} / \mathrm{g}$. The two hundred eighty nine samples have been divided into ten groups: femur (Femur), rib (Rib), other type (Bones), outer layer of femur (Fermur Surf.), outer layer of rib(Rib Surf.), outer layer of other type of bones (Bones Surf.), soil close to the femur (Femur Soil), soil close the rib (Rib Soil), soil of the excavation (Soil), soil close to the other type of bones (Bones Soil). The obtained mean concentrations with their standard deviations and number of analyzed samples can be observed in Table 2 for six groups (Femur, Femur Surf., Rib, Rib Surf., Femur Soil, Rib Soil) and in Table 3 for four groups (Bones, Bones Surf., Bones Soil, Soil).

\begin{tabular}{|c|c|c|c|c|c|}
\hline Element & Wavelength [nm] & Mass [Da] & LOD & LOQ & $\mathbf{R}^{2}$ \\
\hline $\mathrm{Ca}$ & 317.933 & - & 1600 & 5400 & 0.9996 \\
\hline $\mathrm{Sr}$ & 421.552 & - & 4 & 13 & 0.9995 \\
\hline Mg & 285.213 & - & 0.4 & 1.3 & 0.9999 \\
\hline $\mathrm{Zn}$ & 206.2 & - & 0.4 & 1.2 & 0.9998 \\
\hline $\mathrm{Cu}$ & 327.393 & - & 0.11 & 0.4 & 0.9999 \\
\hline $\mathrm{Ba}$ & 233.527 & - & 0.08 & 0.3 & 0.9999 \\
\hline $\mathrm{Mn}$ & 257.61 & - & 0.14 & 0.5 & 0.9997 \\
\hline $\mathrm{Re}^{*}$ & 197.248 & - & & & \\
\hline La & - & 139 & 0.0004 & 0.0014 & 0.9997 \\
\hline $\mathrm{Ce}$ & - & 140 & 0.0005 & 0.0018 & 0.9997 \\
\hline $\mathrm{Pr}$ & - & 141 & 0.00010 & 0.0003 & 0.9997 \\
\hline $\mathrm{Nd}$ & - & 142 & 0.0003 & 0.0010 & 0.9985 \\
\hline $\mathrm{Sm}$ & - & 152 & 0.0003 & 0.0011 & 0.9999 \\
\hline Eu & - & 151 & $6 \mathrm{E}-05$ & 0.00018 & 0.9998 \\
\hline Gd & - & 158 & 0.00015 & 0.0005 & 0.9998 \\
\hline $\mathrm{Tb}$ & - & 159 & $5 \mathrm{E}-05$ & 0.00017 & 0.9977 \\
\hline Dy & - & 162 & $1.1 \mathrm{E}-05$ & $4 \mathrm{E}-05$ & 0.9998 \\
\hline Ho & - & 165 & $3 \mathrm{E}-05$ & 0.00011 & 0.9983 \\
\hline $\mathrm{Er}$ & - & 166 & 0.00013 & 0.0005 & 0.9999 \\
\hline $\mathrm{Tm}$ & - & 169 & $1.6 \mathrm{E}-05$ & $5 \mathrm{E}-05$ & 0.9985 \\
\hline $\mathrm{Yb}$ & - & 172 & $7 \mathrm{E}-05$ & 0.0002 & 0.9999 \\
\hline Lu & - & 175 & $1.7 \mathrm{E}-05$ & $6 \mathrm{E}-05$ & 0.9991 \\
\hline $\mathrm{Sc}$ & - & 45 & 0.013 & 0.04 & 0.9998 \\
\hline Y & - & 89 & 0.0005 & 0.0016 & 0.9996 \\
\hline $\mathrm{Bi}$ & - & 209 & 0.0006 & 0.002 & 0.9999 \\
\hline $\mathrm{Cd}$ & - & 111 & 0.00017 & 0.0006 & 0.9995 \\
\hline $\mathrm{Cr}$ & - & 52 & 0.01 & 0.3 & 0.9986 \\
\hline Co & - & 59 & 0.0004 & 0.0014 & 0.9986 \\
\hline $\mathrm{Pb}$ & - & 207 & 0.0007 & 0.002 & 0.9996 \\
\hline $\mathrm{Li}$ & - & 7 & 0.0002 & 0.0008 & 0.9994 \\
\hline Mo & - & 95 & 0.0011 & 0.004 & 0.9998 \\
\hline $\mathrm{Ni}$ & - & 60 & 0.007 & 0.02 & 0.9996 \\
\hline $\mathrm{TI}$ & - & 205 & $8 \mathrm{E}-05$ & 0.0003 & 0.9999 \\
\hline V & - & 51 & 0.03 & 0.11 & 0.999 \\
\hline $\mathrm{Rh}^{*}$ & - & 103 & & & \\
\hline
\end{tabular}


Table 1: ICP-OES and ICP-MS analysis, Emission wavelengths, mass, detection limits (LOD), quantification limits (LOQ) and $\mathrm{R}^{2}$ of 33 elements. Note: LOD and LOQ expressed in ${ }^{*}$ Internal Standard

For Standard Reference Materials NIST 1400 (bone ash) and GBW07408 (soil), the obtained values are statistically comparable to the certified values.

\begin{tabular}{|c|c|c|c|c|c|c|c|c|c|c|c|c|}
\hline ElEMENTS & Femur & SD & Femur Surf. & SD & Rib & SD & Rib Surf. & SD & Femursoll & SD & Rib Soll & SD \\
\hline${ }^{*} \mathrm{Ca}$ & 365 & 20 & 307 & 33 & 371 & 47 & 239 & 53 & 125 & 16 & 128 & 20 \\
\hline $\mathrm{Sr}$ & 1266 & 299 & 1063 & 331 & 1409 & 300 & 837 & 313 & 198 & 28 & 219 & 59 \\
\hline $\mathrm{Mg}$ & 1328 & 160 & 4000 & 1683 & 1370 & 321 & 6397 & 1681 & 8149 & 596 & 8123 & 1146 \\
\hline $2 n$ & 143 & 31 & 151 & 51 & 218 & $\ddot{\theta}$ & 162 & 77 & 38 & 8 & 42 & 13 \\
\hline cu & 13 & 6 & 20 & 7 & 33 & 18 & 29 & 12 & 14 & 3 & 15 & 6 \\
\hline Ba & 329 & 140 & 545 & 269 & 379 & 2055 & 632 & 255 & 66 & 12 & 111 & 85 \\
\hline $\mathrm{Mn}$ & 48 & 98 & 186 & 152 & 93 & 183 & 283 & 203 & 296 & 47 & 280 & 45 \\
\hline BI & 0.003 & 0.008 & 0.1 & 0.07 & 0.009 & 0.008 & 0.2 & 0.09 & 0.3 & 0.08 & 0.3 & 0.08 \\
\hline cd & 0.3 & 0.2 & 0.3 & 0.14 & 2 & 2 & 1 & 2 & 0.2 & 0.1 & 0.3 & 0.2 \\
\hline $\mathrm{Cr}_{\mathrm{r}}$ & 11 & 4 & 13 & 5 & 12 & 5 & 15 & 6 & 10 & 1 & 10 & 4 \\
\hline co & 2 & 0.7 & 5 & 2 & 2 & 2 & 7 & 3 & 9 & 2 & 8 & 3 \\
\hline $\mathrm{Pb}$ & 61 & 56 & 87 & 63 & 71 & 58 & 84 & 54 & 35 & 14 & 34 & 14 \\
\hline u & 7 & 8 & 19 & 20 & 7 & 11 & 31 & 38 & 26 & 18 & 22 & 30 \\
\hline Mo & 0.6 & 0.3 & 0.8 & 0.3 & 1 & 0.6 & 1 & 0.5 & 0.3 & 0.1 & 0.3 & 0.1 \\
\hline NI & 27 & 8 & 27 & 8 & 29 & 10 & 29 & 9 & 26 & 8 & 25 & 10 \\
\hline ו & 0.01 & 0.1 & 0.1 & 0.1 & 0.006 & 0.1 & 0.2 & 0.1 & 0.2 & 0.1 & 0.2 & 0.1 \\
\hline$v$ & 17 & 7 & 31 & 14 & 22 & 16 & 41 & 22 & 2 & 9 & 25 & 14 \\
\hline La & 0.3 & 0.2 & 9 & 4 & 2 & 1 & 14 & 4 & 17 & 3 & 17 & 3 \\
\hline $\mathrm{Ce}$ & 0.3 & 0.2 & 10 & 6 & 1 & 1 & 18 & 6 & 25 & 5 & 24 & 5 \\
\hline Pr & 0.05 & 0.03 & 2 & 0.9 & 0.3 & 0.2 & 3 & 1 & 4 & 0.8 & 4 & 0.7 \\
\hline $\mathrm{Nd}$ & 02 & 0.1 & 8 & 4 & 1 & 1 & 13 & 4 & 18 & 4 & 17 & 4 \\
\hline $\mathrm{Sm}$ & 0.2 & 0.1 & 2 & 0.9 & 0.4 & 0.2 & 3 & 1 & 3 & 0.8 & 3 & 0.7 \\
\hline Eu & 0.1 & 0.06 & 0.5 & 0.3 & 0.2 & 0.1 & 0.7 & 0.3 & 0.7 & 0.2 & 0.7 & 0.2 \\
\hline Gd & 0.04 & 0.03 & 1 & 0.8 & 0.4 & 0.8 & 3 & 0.9 & 3 & 1 & 4 & 1 \\
\hline $\mathrm{Tb}$ & 0.006 & 0.004 & 0.2 & 0.1 & 0.05 & 0.08 & 0.4 & 0.1 & 0.5 & 0.1 & 0.5 & 0.1 \\
\hline Dy & 0.02 & 0.02 & 0.9 & 0.5 & 0.2 & 0.3 & 2 & 0.5 & 2 & 0.5 & 2 & 0.5 \\
\hline Ho & 0.005 & 0.004 & 0.2 & 0.1 & 0.05 & 0.1 & 0.3 & 0.1 & 0.4 & 0.1 & 0.4 & 0.1 \\
\hline Er & 0.01 & 0.01 & 0.5 & 0.2 & 0.1 & 0.2 & 0.8 & 0.3 & 0.9 & 0.2 & 1 & 0.2 \\
\hline $\mathrm{Tm}$ & 0.002 & 0.002 & 0.07 & 0.03 & 0.02 & 0.02 & 0.1 & 0.04 & 0.1 & 0.03 & 0.1 & 0.03 \\
\hline$Y_{b}$ & 0.01 & 0.008 & 0.4 & 0.2 & 0.09 & 0.1 & 0.6 & 0.2 & 0.7 & 0.2 & 0.7 & 0.2 \\
\hline Lu & 0.002 & 0.002 & 0.06 & 0.03 & 0.02 & 0.02 & 0.08 & 0.04 & 0.1 & 0.03 & 0.1 & 0.03 \\
\hline Sc & 0.4 & 0.3 & 2 & 2 & 0.6 & 0.8 & 3 & 2 & 3 & 2 & 3 & 2 \\
\hline y & 0.2 & 0.1 & 6 & 2 & 2 & 1 & 8 & 2 & 9 & 1 & 9 & 2 \\
\hline N.S. & 32 & & 32 & & 64 & & 62 & & 7 & & 21 & \\
\hline
\end{tabular}

Table 2: Mean concentrations of mayor, trace and Rare Earth Elements of samples and their standard deviations (SD) of six groups. Note: Value expressed in $\mu \mathrm{g} / \mathrm{g}$, ${ }^{*} \mathrm{Ca}$ expressed in $\mathrm{mg} / \mathrm{g}$. Number of Samples (N.S.)

\section{Revealing the intraskeletal impact of diagenetic factors applying PCA}

Figure 1 shows the results obtained from PCA which was employed for gaining a deeper insight into the complex dataset. The first principal component $(\mathrm{PC} 1)$ contains the main part of the variance in the data $(59.54 \%)$. Scores plots represent data points (i.e. samples) projected into the calculated PC space. They are frequently used for data exploration, as the distance between samples can be related to their similarity. From the scores plot shown in Figure 1a, as expected, it can be appreciated that soil samples are clearly different from bone samples. A more significant finding is that the spatial ordering of the samples was clearly visible in the PC scores plot: bone samples from the outer bone layer are located between soil samples and bone samples. Having a closer look at PC1, it can be seen that the group variance of femur samples is smaller than observed for rib samples and hence, this type of bone is recommendable due to its homogeneity.
Furthermore PC1 captures variance explaining differences between out layer part of femur (Femur surf.) and out layer part of rib (Rib surf.). In fact samples obtained from the rib surface seem to be more similar to the soil class (Soil) than the out layer part of the femur, it may be because rib is mainly composed of spongy tissue and therefore more susceptible to diagenesis than femur [34].

\begin{tabular}{ccccccccc}
\hline ELEMENTS & Bones & SD & Bones Surf. & SD & Bones Soll & SD & Soll & SD \\
\hline "Ca & 356 & 27 & 292 & 71 & 123 & 15 & 130 & 16 \\
$\mathrm{Sr}$ & 1162 & 293 & 851 & 240 & 227 & 54 & 234 & 44 \\
$\mathrm{Mg}$ & 1395 & 175 & 3965 & 1687 & 8449 & 1189 & 8572 & 788 \\
$\mathrm{Zn}$ & 130 & 21 & 147 & 139 & 42 & 14 & 42 & 12 \\
$\mathrm{Cu}$ & 21 & 12 & 24 & 16 & 17 & 6 & 19 & 8 \\
$\mathrm{Ba}$ & 364 & 267 & 667 & 783 & 105 & 62 & 95 & 55 \\
$\mathrm{Mn}$ & 26 & 28 & 141 & 83 & 285 & 70 & 309 & 51 \\
$\mathrm{Bl}$ & 0.006 & 0.006 & 0.09 & 0.06 & 0.3 & 0.2 & 0.3 & 0.2 \\
$\mathrm{Cd}$ & 0.3 & 0.2 & 0.3 & 0.1 & 0.2 & 0.2 & 0.2 & 0.06 \\
$\mathrm{Cr}$ & 12 & 10 & 10 & 3 & 10 & 4 & 12 & 4 \\
$\mathrm{CO}$ & 2 & 0.4 & 4 & 2 & 8 & 2 & 10 & 5 \\
$\mathrm{~Pb}$ & 38 & 33 & 91 & 180 & 40 & 29 & 41 & 27 \\
$\mathrm{LI}$ & 7 & 8 & 14 & 12 & 21 & 10 & 39 & 51 \\
$\mathrm{Mo}$ & 0.6 & 0.4 & 0.7 & 0.3 & 0.3 & 0.1 & 0.5 & 0.2 \\
$\mathrm{NI}$ & 24 & 6 & 23 & 7 & 20 & 5 & 22 & 8 \\
$\mathrm{TI}$ & 0.04 & 0.1 & 0.1 & 0.1 & 0.2 & 0.1 & 0.2 & 0.2 \\
$\mathrm{~V}$ & 17 & 6 & 26 & 8 & 26 & 8 & 33 & 19 \\
$\mathrm{La}$ & 0.7 & 0.9 & 9 & 4 & 18 & 8 & 18 & 4 \\
$\mathrm{Ce}$ & 0.5 & 0.6 & 9 & 6 & 27 & 12 & 26 & 6 \\
$\mathrm{Pr}$ & 0.1 & 0.2 & 2 & 0.9 & 4 & 2 & 4 & 1 \\
$\mathrm{Nd}$ & 0.5 & 0.7 & 8 & 4 & 19 & 7 & 17 & 4 \\
$\mathrm{Sm}$ & 0.3 & 0.3 & 2 & 0.8 & 3 & 1.4 & 3.0 & 0.8 \\
$\mathrm{Eu}$ & 0.1 & 0.1 & 0.4 & 0.2 & 0.7 & 0.3 & 0.7 & 0.2 \\
$\mathrm{Gd}$ & 0.09 & 0.1 & 1 & 0.8 & 3 & 1 & 3 & 0.8 \\
$\mathrm{~Tb}$ & 0.01 & 0.02 & 0.2 & 0.1 & 0.5 & 0.2 & 0.4 & 0.1 \\
$\mathrm{Dy}$ & 0.06 & 0.09 & 0.9 & 0.5 & 2 & 0.8 & 2 & 0.5 \\
$\mathrm{Ho}$ & 0.01 & 0.02 & 0.2 & 0.1 & 0.4 & 0.2 & 0.4 & 0.1 \\
$\mathrm{Er}$ & 0.03 & 0.05 & 0.5 & 0.2 & 1 & 0.4 & 0.9 & 0.3 \\
$\mathrm{Tm}$ & 0.005 & 0.007 & 0.07 & 0.03 & 0.1 & 0.1 & 0.1 & 0.04 \\
$\mathrm{Yb}$ & 0.02 & 0.04 & 0.4 & 0.2 & 0.8 & 0.3 & 0.7 & 0.2 \\
$\mathrm{Lu}$ & 0.005 & 0.007 & 0.06 & 0.03 & 0.1 & 0.05 & 0.1 & 0.04 \\
$\mathrm{SC}$ & 0.3 & 0.2 & 2 & 0.8 & 3 & 0.9 & 4 & 3 \\
$\mathrm{Y}$ & 0.4 & 0.7 & 5 & 2 & 9 & 2 & 9 & 2 \\
\hline $\mathrm{N} . \mathrm{S}$. & 22 & & 22 & & 13 & & 14 & \\
\hline & & & & & & & &
\end{tabular}

Table 3: Mean concentrations of mayor, trace and Rare Earth Elements of samples and their standard deviations (SD) of four groups. Note: Value expressed in $\mu \mathrm{g} / \mathrm{g},{ }^{\star} \mathrm{Ca}$ expressed in $\mathrm{mg} / \mathrm{g}$. Number of Samples (N.S).

In the loadings plot shown in Figure $1 \mathrm{~b}$, the contribution of each variable (i.e. elements) to the $\mathrm{PC} 1$ is represented, being the absolute intensity of the loading of each variable directly correlated with its magnitude of contribution to the model and the sign with its direction. As explained above, PC1 contains useful information for differentiating bone, outer layer part of femur, outer layer part of rib and soil samples.

These results indicate that the bone surface of ribs is suffering a mayor degree of diagenetic processes than the bone surface of femur. The shown data suggest that outer layer parts of bones belonging to different skeletal areas have not suffered the same digenetic impact. From the intensities and signs of the loadings on PC1, Ca, Sr and $\mathrm{Zn}$ can be identified to show higher concentrations in bone samples than soil samples. Conversely, the relative concentrations of $\mathrm{Mg}$, Mn, REEs (La-Lu), Sc, Y, Bi, Co, Tl are lower in bone samples than in the out layer part of femur, the outer layer part of rib as well as in soil samples. 


\section{a}

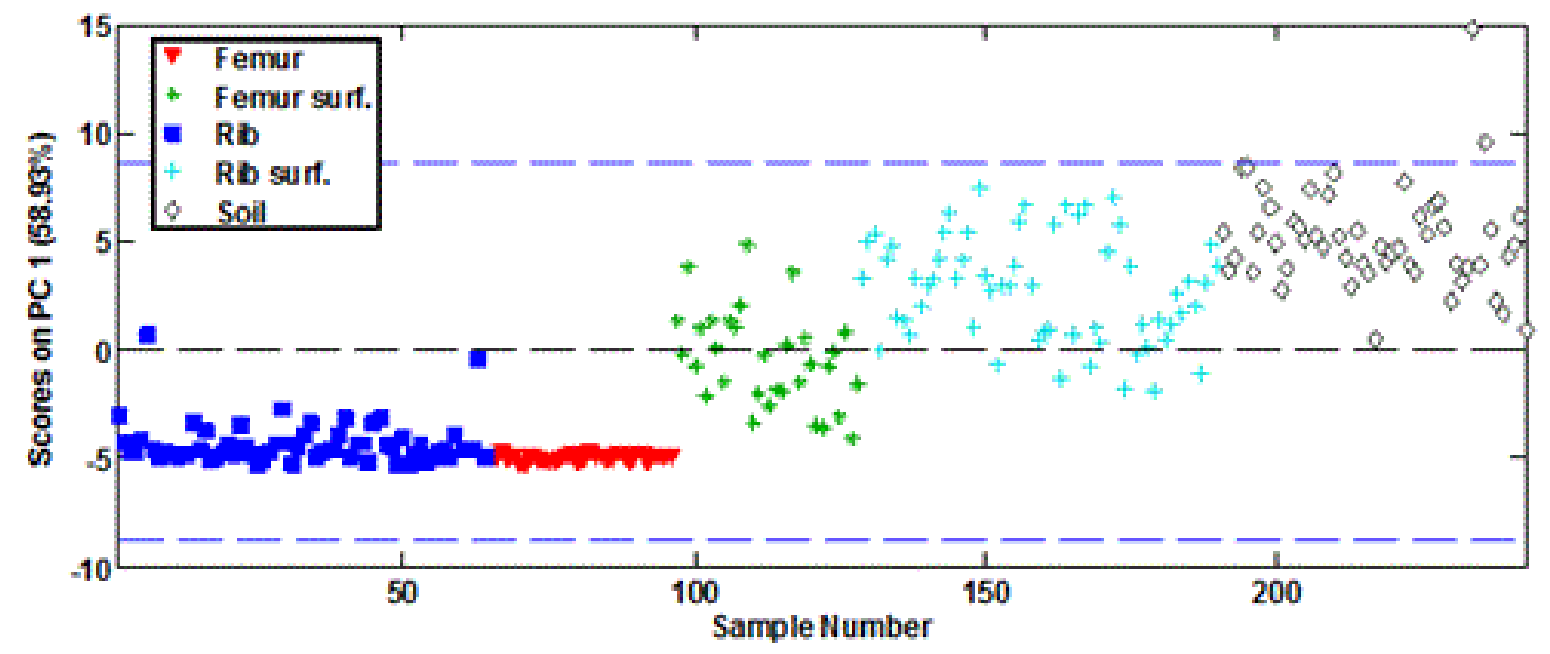

b

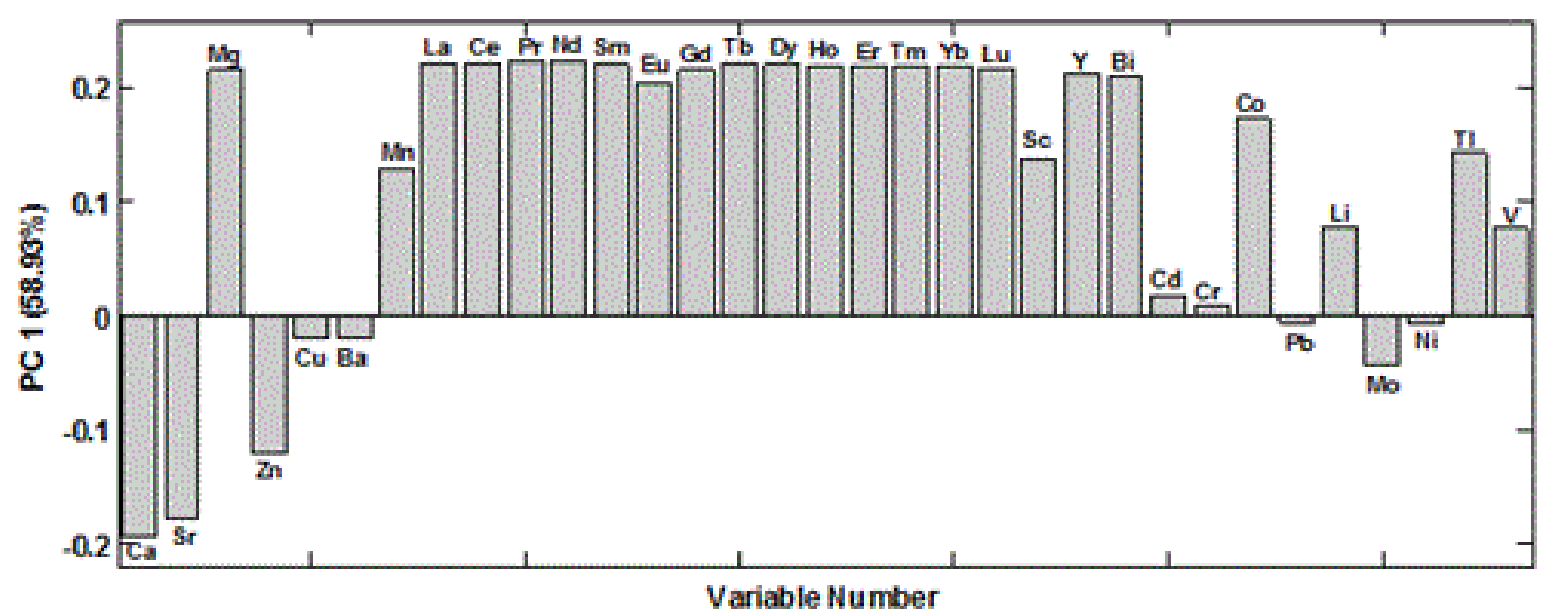

Figure 1a and 1b: Results PCA. Scores (top) and loadings (bottom) on PC1.

\section{Classification of diverse bones employing PLSDA}

In biochemical-forensic studies elemental alteration caused by sediments to different classes of bones has to be taken into account to avoid erroneous interpretations about pathologies, nutrition, injuries and other forensic issues. Moreover there is a correlation between bone classes and diagenetic impact (different bones can suffer postmortem processes differently). However, a-priori class assignment is not always possible. To overcome this difficulty, PLSDA has been applied to classify bone samples from the cortical part of femurs and cortical part of ribs using their elemental profile. A calibration set was built including samples belonging to the classes "Femur" and" Rib" for model calculation. In addition, using "Femur" and" Rib" samples which have not been included in the calibration set, an external validation set was built. As shown in Figure 2a, for both calibration and validation sets, good class separation between ribs and femurs have been obtained using a PLSDA model employing one latent variable. From the regression vector shown in Figure $2 \mathrm{a}$, it can be observed that $\mathrm{Zn}, \mathrm{Cu}$, La, Ce, Pr, Nd, Sm, Eu, Gd, Tb, Dy, Ho, Er, Tm, $\mathrm{Yb}, \mathrm{Lu}, \mathrm{Y}, \mathrm{Bi}$ and Mo show elevated concentrations in rib samples. This model was applied to a set of bones belonging to different classes of cortical bones which were not used for model calibration or validation (test set). As it can be appreciated from Figure 2a and $2 \mathrm{~b}$ most of bone samples (humerus, skull, tibia, radius) are similar to femurs except for the child's humerus, child's large bone (Large Child) and the child's spongy bone, which were similar to the rib class. Due to the result of the statistical test, bone samples containing a major chemical element 
soil contamination could be identified. Although a greater interaction between soil and some bone classes marked by the REEs contents could be identified, reflecting an increase of some trace elements such as $\mathrm{Zn}, \mathrm{Cu}, \mathrm{Y}, \mathrm{Bi}$ and $\mathrm{Mo}$, no correlation has been observed between the highest REEs values, and diagenesis impact on $\mathrm{Ca}, \mathrm{Sr}, \mathrm{Mg}, \mathrm{Ba}, \mathrm{Mn}, \mathrm{Sc}$,
$\mathrm{Bi}, \mathrm{Cd}, \mathrm{Cr}, \mathrm{Co}, \mathrm{Pb}, \mathrm{Li}, \mathrm{Ni}, \mathrm{Tl}$ and $\mathrm{V}$ concentrations, which remain similar in all bone classes. Higher $\mathrm{Ca}$ values are justified by its elevated biological content. $\mathrm{Sr}, \mathrm{Mg}, \mathrm{Ba}, \mathrm{Mn}, \mathrm{Sc}, \mathrm{Bi}, \mathrm{Cd}, \mathrm{Cr}, \mathrm{Co}, \mathrm{Pb}, \mathrm{Li}, \mathrm{Ni}, \mathrm{Tl}$ and $\mathrm{V}$, probably are equally affected in all bones by taphonomic processes.
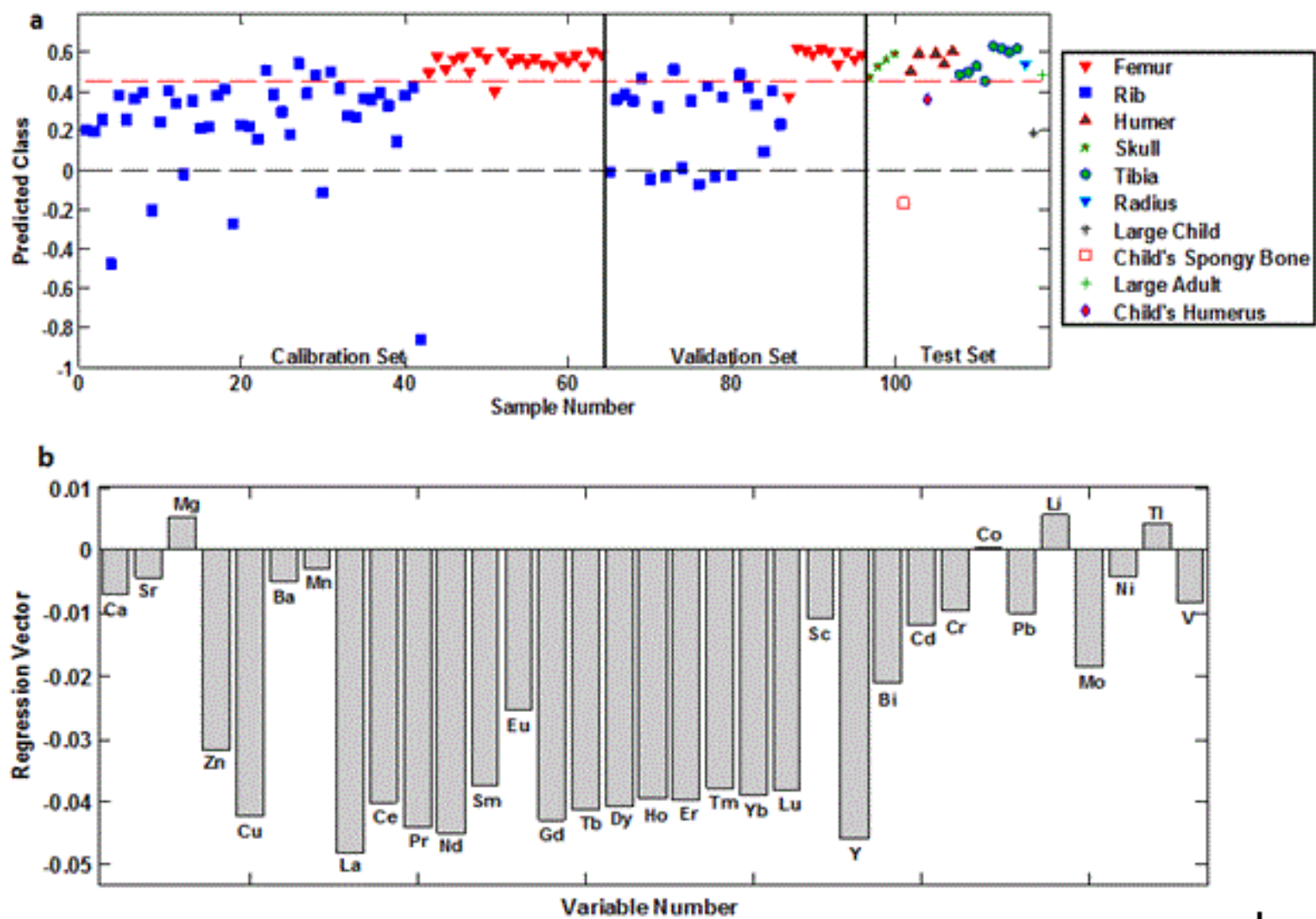

Figure 2: Results PLSDA. Predicted class membership of samples contained in the calibration, validation, and the test data set (a) and regression vector of the PLSDA model (b).

Separation between femurs and ribs in the model could be explained by the differences in mineralogical density, where ribs are mainly composed of spongy tissue and are more susceptible to diagenetic processes. In contrast femurs and other bones (humerus, skull, tibia, radius), given to their denser mineralization, are less influenced by soil contamination and environmental chemical element changes. Consequently the semblance in chemical elements of ribs with the child's humerus, child's large bone and the child's spongy bone may be induced by lesser mineralization and thinner cortex that make those bones prone to post-mortem contamination [6].

The established PLSDA model was validated employing permutation testing. The results of the permutation test using single $\mathrm{CV}$ and one LV are shown in Figure 3. This figure displays the correlation coefficient between the original and the permuted class vectors versus the standardized SSQ. It can be seen that the selfpredicted standardized SSQ values after class permutation always showed values close to one independently from their correlation with the real class values $[43,44]$.

Conversely, CV showed that PLSDA models built from permuted class labels with a low correlation to real class values resulted in significantly lower values of standardized SSQ. A p-value of 0.013 was obtained for cross-validation, by employing a randomization t-test, thus confirming the significance of the original PLSDA model at a $95 \%$ confidence level. Results from the permutation test show that the PLSDA model built for the classification of rib and femur samples is not due to chance correlations and it can be considered to be highly significant and reliable. 


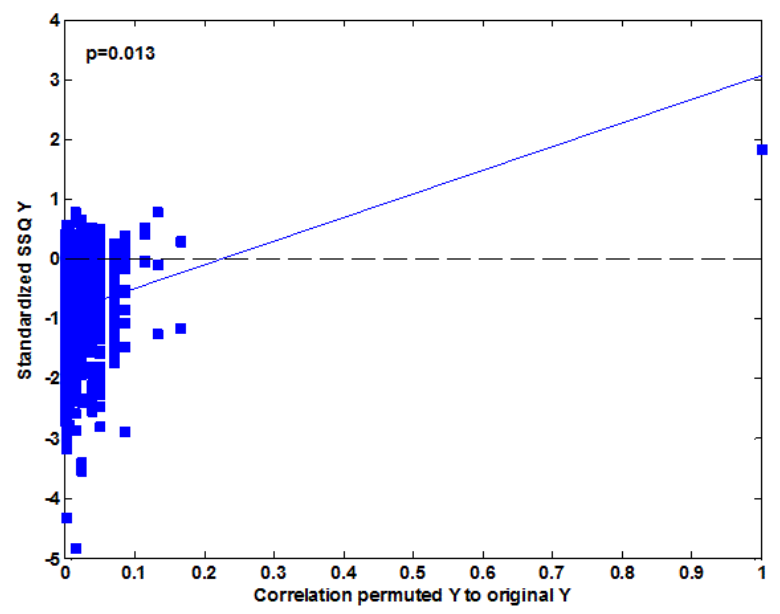

Figure 3: Results of the permutation test using the calibration data and the calculated PLSDA model for bone sample classification of rib vs. femur.

\section{Diet profile changes depending on the bone classes}

Diet reconstruction has been carried out employing different bones classes to test the interpretive errors that take actions without consider diagenetic factors. Conventionally, diet studies have employed $\mathrm{Zn} / \mathrm{Ca}$ relations to identify higher or lower protein intake and $\mathrm{Sr} / \mathrm{Ca}$ to identify pastoral or agricultural societies. $\mathrm{Zn} / \mathrm{Ca}$ reference values $>0.5$ equivalent to a diet rich in protein and $<35$ equivalent to a diet poor in protein were employed [45,46]. Sillen and Kavanagh (1982) reference values were taken into consideration for $\mathrm{Sr} / \mathrm{Ca}$ relation where $>0.7$ identifies an agricultural economy (vegetable), $<0.4$ a pastoral economy (milk and meat) and values between $0.4-0.7$ a mixed economy (vegetable, milk and meat) $[45,46]$. Diet and economy, depending on the semblance of the different bone classes to one or another value, were associated (Figure $4 \mathrm{a}$ and $\mathrm{b}$ ). Interesting results are observed for the relation of $\mathrm{Zn} / \mathrm{Ca}$ (Fig.4a). The groups of femur, humerus, parietal (SKULL), tibia, radius and large adult bones (LARGE ADULT) are related to a poor protein diet intake. Conversely, the groups of ribs (RIB), child's large bone (LARGE CHILD) and child'sspongy bone are related to a rich protein diet intake, except the child's humerus that is similar to the femurs diet profile. The relation $\mathrm{Sr} / \mathrm{Ca}$ shows that all the group profiles are related to a mayor intake of vegetable except for radius that present a mix diet (intake of vegetables and as well as meat and dairies).

It was observed that the groups of rib and the child bones except the humerus present contradictions in their established diet profile, as a mayor intake of protein is not related to a vegetable diet. The difference in diet profiles of child's humerus and rib groups are probably due to $\mathrm{Zn}$ values similar to the femur group, as reflected by PLSDA. In fact child's humerus is the only sample classified to the rib side, but very close to the femur group. Resuming, diet reconstruction employing $\mathrm{Zn} / \mathrm{Ca}$ and $\mathrm{Sr} / \mathrm{Ca}$ parameters has shown that, depending on the class of bones analyzed, conclusions about people life-style could change.

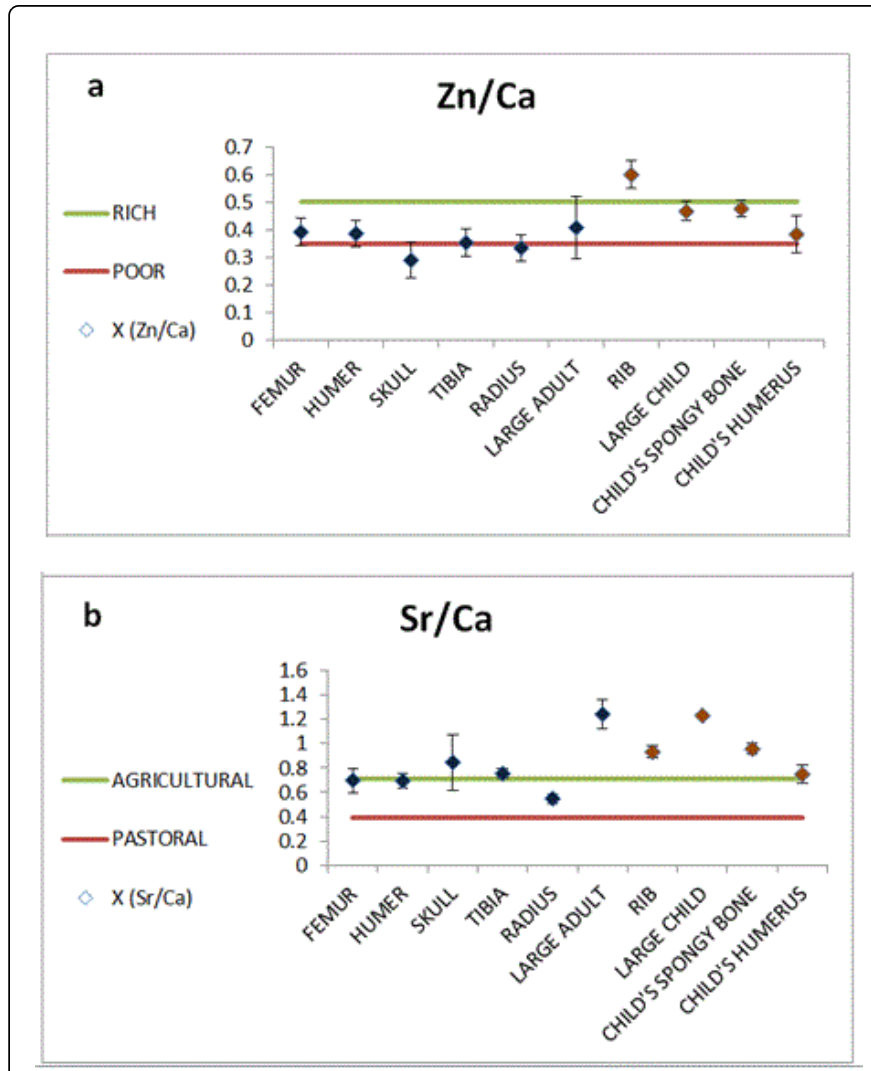

Figure 4: $\mathrm{Zn} / \mathrm{Ca}$ relation results (a): diet with high intake of protein (RICH); diet with low intake of protein (POOR) and $\mathrm{Sr} / \mathrm{Ca}$ relation results (b): Agricultural economy (AGRICULTURAL); pastoral economy (PASTORAL). Groups classified by PLSDA.

Statistical classification and chemical analyses of buried bones belonging to different skeletal areas has been shown to be a useful tool, to control diagenetic factors in order to decide whether a sample is suitable or not for biochemical-forensic studies.

\section{Conclusions}

ICP-OES and ICP-MS analysis have shown to be adequate techniques for the determination of the elemental composition of samples. PCA has shown that the elemental profile of bone and soil samples, as expected, is clearly different. Furthermore the group of the out layer part of ribs is more similar to the soil class (Soil) than the out layer part of the femur. This indicates that the elemental profile of the outer bone layer of rib is more altered in comparison to the outer layer part of the femur as it is more similar to soil samples withdrawn from the surroundings of the place of finding. This may be due to diagenetic factors that are more evident in rib surface, because rib is mainly composed of spongy tissue and is more susceptible to diagenesis than femur surface, as indicated by higher REEs concentrations. The statistical results provided evidence that diagenesis in the surface layers of skeletal bones belonging to different sectors does not have the same impact. Consequently, the use of elemental profiles found in outer bone layers for biochemical-forensic studies is not recommended, because they could be masked by diagenetic factors and, therefore, misleading conclusions could be obtained. 
Page 8 of 9

Results from PLSDA confirmed a major enrichment of REEs, Y, Zn, $\mathrm{Cu}, \mathrm{Bi}$ and $\mathrm{Mo}$ in ribs. Furthermore child bones are assigned to the class of ribs, probably due to the similarity in mineral density that leads to a similar interaction of the chemical elements with the sediments. In child bones, lesser mineralization and the thinner cortex make those bones prone to post-mortem contamination. Femurs are different from ribs and the distribution of different bone classes, depending on their elemental composition, has been shown to be feasible. This means that when we want to identify the degree of diagenetic impact in a population and at intra-skeletal levels, statistical analysis can help to classify different bones according to their elemental profile. These preliminary results suggest that femur, humerus, radius, tibia and parietal have undertaken less diagenesis than rib and child bones as they have significantly lower concentrations of REEs. A lower post-mortem incorporation of exogenous elements may have caused mayor mineralogical density in femur, humerus, radius, tibia and parietal. Trace elements such as $\mathrm{Zn}$, $\mathrm{Cu}, \mathrm{Y}, \mathrm{Bi}$ and $\mathrm{Mo}$ seem to follow the same behaviour of REEs enrichments from soils in ribs and child bones. Although a greater interaction between soil and some bone classes marked by REEs contents could be seen, reflecting an increase of some trace elements, no correlation has been observed between the highest content of REEs, and the impact of diagenesis on the remaining elements $(\mathrm{Ca}, \mathrm{Sr}, \mathrm{Mg}$, $\mathrm{Ba}, \mathrm{Mn}, \mathrm{Sc}, \mathrm{Bi}, \mathrm{Cd}, \mathrm{Cr}, \mathrm{Co}, \mathrm{Pb}, \mathrm{Li}, \mathrm{Ni}, \mathrm{Tl}$ and $\mathrm{V}$ ). In case of $\mathrm{Ca}$ this may be due to higher biological contents. For the other elements, soil contamination has equally affected the bones.

Experimental tests employing $\mathrm{Zn} / \mathrm{Ca}$ and $\mathrm{Sr} / \mathrm{Ca}$, traditional diet parameters, have shown that diet profiles of a population could change depending on the class of bones analyzed.

Consequently, for forensic investigations, the analysis of major elements, trace elements and REEs is suggested in combination with the statistical classification of bones exposed to different degrees of diagenesis and bones belonging to different skeletal sectors, along with experimental studies of modern bones. Diagenetic factors caused by the environment can be controlled by soil analysis and the first layer on the surface of the bones employing ICP-OES and ICP-MS analysis and statistical tools in order to decide whether a sample is suitable or not for biochemical studies.

Upcoming studies applying statistical methods are already in due course, in order to understand how the impacts of taphonomic processes in inorganic bone matter, presented in our study, are related with the quality of the organic matter conservation of the same sample collections.

\section{Acknowledgement}

The authors gratefully acknowledge the help from Domingo Carlos Salazar of the Department of Human Evolution of Max-Planck Institute for Evolutionary Anthropology (Leipzig, Germany) and Albert Ribera, Pepa Pascual, Josep Vicent Lerma of SIAM (Valencia Town Council) for providing the samples used in this study, also the archaeologist Miguel Roselló for providing the archaeological excavation data. JK acknowledges the "Sara Borrell" grant from the Instituto Carlos III (Spanish Ministry of Economy and Competitiveness).

\section{References}

1. Hedges REM, Millard AR (1995) Bones and groundwater: towards the modelling of diagenetic processes. Journal of Archaeological Science 22: 155-164.

2. Hedges REM (2002) Bone diagenesis: an overview of processes, Archaeometry, 44: 319-328.

3. Hinz EA, Kohn MJ (2010) The effect of tissue structure and soil chemistry on trace element uptake in fossil. Geochimica et Cosmochimica Acta 74: 3213-3231.

4. Lambert JB, Xue L, Buikstra JE (1991) Inorganic analysis of excavated human bone after surface removal. Journal of Archaeological Science18: 363-383.

5. Pate D, Hutton JT (1988) The use of soil chemistry data to address postmortem diagenesis in bone mineral. Journal of Archaeological Science 15: 279-739.

6. Zapata J, Pérez-Sirvent C, Martínez-Sánchez MJ, Tovar P (2006) Diagenesis, not biogenesis: Two late Roman skeletal examples. Sci Total Environ 369: 357-368

7. Reiche I, Favre-Quattropani L, Calligaro TJS, Bocherens H, Charlet L et al., (1999) Trace element composition of Archaeological Bones and postmortem alteration in the burial environment. Nuclear Instruments and Methods. Physics Research B 150: 656-662.

8. Schmidt-Schultz TH, Schultz M (1999) Intact protein molecules in archaeological bones - Bone matrix as a treasure chest of ancient diseases and living conditions. American Journal of Physical Anthropology. Annual Meeting Issue 1999, Wiley-Liss, 230.

9. Surovell TA, Stiner MC (2001) Standardizing Infra-red measures of bone mineral crystallinity: an experimental approach. Journal of Archaeological Science. 28: 633-642.

10. Rasmussen KL, Bjerregaard P, Halkjaer Gommesen P, Lass Jensen O (2009) Arsenic in Danish and Swedish Mesolithic and Neolithic human bones - diet or diagenesis? Journal of Archaeological Science 36: 2826-2834.

11. Rebôcho J, Carvalho ML, Marques AF, Ferreira FR, Chettle DR (2006) Lead post-mortem intake in human bones of ancient populations by (109)Cd-based X-ray fluorescence and EDXRF. Talanta 70: 957-961.

12. Domingo L, Cuevas-Gonzáles J, Grimes ST, Hernández Fernández M, López-Martínez (2009) Multiproxy recostruction of the palaeoclimate and palaeoenviroment of the Middle Miocene Somosaguas site (Madrid, Spain) using herbivore dental enamel. Palaeogeography, Palaeoclimatology, Palaeoecology 272: 53-68.

13. Kohn MJ (2008) Models of diffusion-limited up-take of trace elements in fossils and rates of fossilization. Geochimica et Cosmochimica Acta 72: 3758-3770.

14. Morad S, Felitsyn S (2001) Identification of primary Ce-anomaly signatures in fossil biogenic apatite: implication for the Cambrian oceanic anoxia and phosphogenesis. Sediment. Geol. 143: 259-264.

15. Trueman CN, Tuross N (2002) Trace elements in recent and fossil bone apatite. In: Kohn MJ, Rakovan J, Hughes J M, (Eds.), Phosphates: Geochemical, Geobiological and Materials Importance. Reviews in Mineralogy and Geochemistry. Mineralogical Society of America. Washington, D.C.48: 489-521.

16. Trueman CNG, Behrensmeyer AK, Tuross N, Weiner S (2004) Mineralogical and compositional changes in bones exposed on soil surfaces in Amboseli National Park, Kenya: diagenetic mechanisms and role of sediment pore fluids. Journal of Archaeological Science 31: 721-739

17. Trueman CN, Privat K, Field J (2008) Why do crystallinity values fail to predict the extent of diagenetic alteration of bone mineral? Palaeogeography, Palaeoclimatology, Palaeoecology 266: 160-167.

18. Trueman CN, Palmer MR, Field J, Privat K, Ludgate N (2008) Comparing rates of recrystallisation and the potential for preservation of biomolecules from the distribution of trace elements in fossil bones. General Paleontology ( Taphonomy and Fossilization) 7: 145-158 
19. Trueman CN (2004) Forensic geology of bone mineral: geochemical tracers for post-mortem movement of bone remains. Forensic Geosciences, Principles, Techniques and Applications, Pye, K., and. Croft, D.J., (Eds.).The Geological Society of London, London, 249-256.

20. Kocsis L, Trueman CN, Palmer MR (2010) Protracted diagenetic alteration of REE contents in fossil bioapatites: Direct evidence from LuHf isotope systemtics. Geochimica et Cosmochimica Acta 74: 6077-6092.

21. Zaichick S, Zaichick V, Karandashev V, Nosenko S (2011) Accumulation of rare earth elements in human bone within the lifespan. Metallomics 3: 186-194.

22. Denys C, Williams CT, Dauphin Y, Andrews P, Fernandez-Jalvo Y, 1996. Diagenetical changes in Pleistocene small mammal bones fron Olduva Bed I. Palaeogeography, Palaeoclimatology, Palaeoecology 126: 121-134.

23. Iliopoulos G, Galanidou N, Pergantis SA, Vamvakaki V, Chaniotakis (2010) Identifying the geochemical taphonomy of the osteological material from Katsambas rockshelter. Journal of Archaeological Science 37: 116-123.

24. Macfadden BJ, Hulbert RC (2009) Calibration of mammoth (Mammuthus) dispersal into North America using rare earth elements of Plio-Pleistocene mammals from Florida. Quaternary Research 71: 41-48.

25. Patrick D, Martin JE, Parris DC, Grandstaff DE (2004) Paleoenvironmental interpretations of rare earth element signatures in mosasaurs (reptilia) from the upper Cretaceous Pierre Shale, central South Dakota, USA. Palaeogeography, Palaeoclimatology, Palaeoecology 212: $277-294$

26. Trueman CN, Benton MJ (1997) A geochemical method to trace the taphonomic history of reworked bones in sedimentary settings. Geology 25: 263-266

27. Trueman CNG, Behrensmeyer AK, Potts R, Tuross N (2006) Highresolution records of location and stratigraphic provenance from the rare earth element composition of fossil bones. Geochim. Cosmochim. Acta 70: 4343-4355.

28. Tütken T, Vennemann T (2011) Fossil bones and teeth: Preservation or alteration of biogenic compositions, Palaeogeography, Palaeoclimatology, Palaeoecology 310: 1-8.

29. Williams CT, Henderson P, Marlow CA, Molleson TI (1997) The environment of deposition indicated by the distribution of rare earth elements in fossil bones from Olduvai Gorge, Tanzania. Applied Geochemistry 12: 537-547.

30. Bell LS, Cox G, Sealy J (2001) Determining isotopic life history trajectories using bone density fractionation and stable isotope measurements: a new approach. American Journal of Physical Anthropology 116: 66-79.

31. Shin JY, Hedges REM (2012) Diagenesis in bone and enamel apatite carbonate; the potential of density separation to assess the original composition. Journal of Archaeological Science 39: 1123-1130.
32. Shin JY, O'Connel, Black S, Hedges R (2004) Differentiating bone osteonal turnover rates by density fractionation; validation using the bomb 14C atmospheric pulse. Radiocarbon 46: 853-861.

33. Maurer AF, Gerard M, Person A, Barrientos I, Del Carmen Ruiz P et al., (2011) Intra-skeletal variability in trace elemental content of Precolumbian Chupicuaro human bones: the record of post-mortem alteration and a tool for paleodietary reconstruction. Journal of Archaeological Science 38: 1784-1797.

34. Lambert JB, Vlasak SM, Thometz AC, Buikstra JE (1982) A comparative study of the chemical analysis of ribs and femurs in Woodland populations. Am J Phys Anthropol 59: 289-294.

35. Roselló Mesquida M, Ruiz Val E (1996) La necrópolis occidental de la Valencia romana. Saitabi 46: 147-168.

36. Gallello G, Kuligowski J, Pastor A, Diez A, Bernabeu J (2013) Biological mineral content in iberian skeletal cremains for control of diagenetic factors employing multivariate statistics. Journal of Archaeological Science 40: 2477-2484.

37. Jolliffe EIT (2002) Principal Component Analysis, second edition, Springer-Verlag, New York.

38. Barker M, Rayens W (2003) Partial least squares for discrimination. Journal of Chemometrics 17: 166-173.

39. Hobro AJ, Kuligowski J, Döll M, Lendl B (2010) Differentiation of walnut wood species and steam treatment using ATR-FTIR and partial least squares discriminant analysis (PLS-DA). Anal Bioanal Chem 398: 2713-2722.

40. Solberg R, Escobar J, Arduini A, Torres-Cuevas I, Lahoz A, et al. (2013) Metabolomic Analysis of the Effect of Postnatal Hypoxia on the Retina in a Newly Born Piglet Model. PLoS One 8: e66540.

41. Kuligowski J, Carrión D, Quintás G, Garrigues S, De La Guardia M (2011) Sample classification for improved performance of PLS models applied to the quality control of deep frying oils of different botanic origins analyzed using ATR-FTIR spectroscopy. Anal Bioanal Chem 399: 1305-1314.

42. Knijnenburg TA, Wessels LF, Reinders MJ, Shmulevich I (2009) Fewer permutations, more accurate P-values. Bioinformatics 25: i161-168.

43. Umetrics (2008) "User Guide to SIMCA-P+", version 12, Kinnelon, USA.

44. Wise BM, Shaver JM, Gallagher NB, Windig W, Bro R et al., (2006) PLS_Toolbox 4.0. Eigenvector Research, Inc., Wenatchee, WA, USA.

45. Fornaciari G, Ciranni R, Busoni CA, Gamba S, Benedetti E (2001) Santa Zita di Lucca: malattie, ambiente e società dallo studio di una mummia naturale del XIII sec. Ed. "All'insegna del Giglio.

46. Mallegni F, Rubini M (1994) Recupero dei materiali scheletrici umani in archeologia, Ed. CISU, Roma 193. 